\title{
The Potential of Developing a Heritage Village to Safeguard Intangible Cultural Heritage from the Perspectives of Stakeholders at Pura Tanjung Sabtu, Terengganu
}

\author{
Noorfathehah binti Abdullah Sani* and Madzlan Bin. Abet \\ Pusat Pendidikan Asas dan Lanjutan Universiti Malaysia Terengganu 21300, Kuala Nerus Terengganu \\ *Corresponding author.noorfathehah.sani@umt.edu.my
}

\begin{abstract}
Since the ratification of Malaysia on the UNESCO 2003 Convention of Safeguarding Intangible Cultural Heritage in July 2013, many elements of intangible cultural heritage is safeguarded, such as theatre, dances, music, oral tradition, performing arts and so on. However, academic study focus less attention to the safeguarding of ICH in a cultural heritage village setting. This paper examines the issues, challenges and potential of safeguarding ICH in a heritage village at Terengganu, Malaysia. It explores how the Pura Tanjung Sabtu heritage village aims to contribute to the safeguarding of local people's heritage. This study based on qualitative data, combining the in-depth interviews with the local community around the area and interview with the heritage and tourism experts or officers in Terengganu, as well as observation at the heritage village. The findings indicate that by safeguarding the heritage village, it makes a crucial contribution to the research and documentation of local people heritage. However, the heritage village struggles to disseminate $\mathrm{ICH}$ expression to the younger generation apart from the autonomy's issues among stakeholders. The research sums up essential criteria to the safeguarding of ICH are to include local community and potential stakeholders in the safeguarding process, for example by employing them in management positions, and to concentrate more strongly on education and transmission.
\end{abstract}

Keywords: culture, heritage village, Intangible cultural heritage

\section{INTRODUCTION}

Cultural Heritage villages are among the most popular choice for tourism destination and they are also the essential tool for safeguarding and protecting the cultural heritage diversity of a country (Yang, 2011) [1]. However, cultural heritage village are hardly considered for their safeguarding function although they have the potential to contribute to the commercialization of cultural heritage (Oakes, 1998)[2]. Heritage village is nothing new as it was widely practiced and have similar concept to that of cultural village, living museum, eco-museum village such as in Australia and France. Malaysia too, has a cultural village located at Melaka World Heritage site, such as the Morten Village, Chitty village, Portuguese settlement, Air Hangat Village, Mahsuri Tomb, Sarawak Cultural Village, Mari Mari Cultural Village which depicting the traditional homes of different ethnic communities. This portray that heritage village can serve both as an tourism facility for tourists and one of the crucial research institutions for safeguarding ICH in Malaysia. Although many experts claimed doubt in the heritage village's effectiveness of safeguarding ICH, in-depth interviews with local community show that several aspects of ICH are needed to be protected through heritage village. This paper explores the role of Pura Tanjung Sabtu in the safeguarding the ICH at Terengganu, Malaysia and analyse the issues, struggles and potential of safeguarding ICH in a cultural heritage village setting.

\section{LITERATURE REVIEW}

Intangible cultural heritage ( $\mathrm{ICH})$ is facing a dire situation globally, and is often because of the rapid modernization 
and urbanization that contribute to the loss of ICH. According to (Zan, 2007)[3], almost each minute, one kind of cultural heritage disappears and the disappearance of ICH traditions is a worldwide issue endangered local, regional and national traditions. Although it sounds a little extreme, it is a fact that cultural heritage all of the world is slowly deteriorated as claimed (Johnson, 2014) [4] that heavy modernization are making them obsolete and destroying the original environments in which they were practiced. It is supported by (Howard, 2012) [5] that there is a growing mind-set that if $\mathrm{ICH}$ is not safeguarded it will result in an irretrievable loss of cultural heritage traditions. Due to that situation, a global framework for the safeguarding of ICH was established; the 2003 UNESCO Intangible Cultural Heritage Convention [6]. According to the framework, $\mathrm{ICH}$ is defined as:

"the practices, representations, expressions, knowledge, skills - as well as the instruments, objects, artefacts and cultural spaces associated therewith - that communities, groups and, in some cases, individuals recognize as part of their cultural heritage. This intangible cultural heritage, transmitted from generation to generation, is constantly recreated by communities and groups in response to their environment, their interaction with nature and their history, and provides them with a sense of identity and continuity, thus promoting respect for cultural diversity and human creativity. For the purposes of this Convention, consideration will be given solely to such intangible cultural heritage as is compatible with existing international human rights instruments, as well as with the requirements of mutual respect among communities, groups and individuals, and of sustainable development. [7]

In a nutshell, the ICH covers the 'heritage that is embodied in people rather than inanimate objects' [6].

The 2003 UNESCO Convention and the first listing of Mak Yong, a form of Malay Traditional Theatre as one of the Masterpieces of the Oral and Intangible Heritage of Humanity for Malaysia in 2005 has triggered Malaysia's interest in embarking actively to safeguard ICH. While the Malaysian Government, previously had paid little interest to the safeguarding of traditional culture, later it identified the safeguarding of ICH as a way to strengthen national unity and patriotism and to develop tourism (Pan 2008) [8]. In 2018, Dondang Sayang was officially recognized by UNESCO as the Representative List of the Intangible Cultural Heritage of Humanity. Previously, the ideas of safeguarding and promoting ICH are heavily influenced by the international framework, because of the unavailability of comprehensive and proper laws or act that highlights the whole idea of ICH at national level.

For ICH, the emphasis on 'excellence' varies from the UNESCO Convention of 2003. Although the ideal of 'extraordinary universal value' and 'excellence' is part of the 1972 UNESCO World Heritage Convention and was a criterion used in the Proclamation of Masterpieces of Intangible Cultural Heritage (2001-2005), it was expressly agreed not to include it in the 2003 Convention, which sought to encourage the fair recognition of diverse cultural traditions (De Cesari 2012) [9]. There are no simple requirements for what constitutes 'excellence,' ICH experts have come to equate it with 'distinctness' [10].

ICH also has a role to play in fostering national unity and a harmonious community. It gives the national government the power to determine which expressions of the ICH are worth preserving and to neglect the ICH, which is less consistent with the current political philosophy (Lixinski 2013) [11]. This is in line with the ideas expressed in Article 15 of the 2003 Convention, which states that the State Party shall strive to ensure the widest possible participation of societies, associations and where necessary, individuals producing, preserving and transmitting such heritage and to actively engage them in its management' [7].

One of the mechanism of protecting ICH is the recognition of heritage village as one of the tourist's attraction because it can assist as the cultural resource for economic value. It is undeniable that heritage in Malaysia is often utilized as a mechanism of economic development [12] and although it sounds more like a commodifying the heritage, there is a justification of why it is commodified. It is called as 'productive protection' which is to increase the national economic development and the transmission of ICH, simultaneously. Business wise, the term is known as commercial approach to safeguarding cultural heritage that converts $\mathrm{ICH}$ resources into cultural products while sustaining their integrity, originality, essence and inheritance (Su, 2015)[13].

Tourism village growth needs the participation of several stakeholders, including government, private sectors and community members (Amerta, 2017) [14]. Cultural heritage is the creation of the village by incorporating attractions, accommodations and facilities presented in the community life structure (Dewi, 2017) [15]. A cultural village should meet at least some of the following requirements: good accessibility, some interesting artifacts, help for community and officials, protection, adequate accommodation and related publicly known objects (Syafi'i et al., 2015) [16]. In developing countries, spatial urban change will affect the economic and social structure of people (Santoso, 2013; Zahnd, 2006)[17]-[18]. This form of change is mainly due to capitalization and modernization pressure (Ishomuddin, 2005)[19]. A heritage area's spatial transition should maintain local identity and social harmony. It was affected by evolving roles, needs, economics, social life (Habraken et al., 1976; Rapo-port, 1969, 1990; Rossi \& Eisenman, 1982) [20][22], activity and lifestyle (Higgins, 2014; Marlina, 2017, cited in Suprati, 2019) [23]-[25].

\section{PURA TANJUNG SABTU, TERENGGANU}

The first thought that comes to mind when one visits Pura Tanjung Sabtu in Kampung Tanjung Sabtu, Manir is now 
"Beautiful yet forgotten." Sanskrit's word "pura" means "palace" and in its glory days this magnificent building, an amalgamation of seven local wooden buildings, would have made an impression. However, after its custodian, Tengku Ismail Tengku Su passed away in 2011, the palace built some 30 years ago struggled to maintain its immaculate appearance, with some pieces of mouldy floorboards and furniture no longer being smoothly put. Situated about $14 \mathrm{~km}$ from Kuala Terengganu and occupying 5.6ha (14 acres of land near Sungai Nerus owned by the royal family, Tujuh Rumah Putera (its other name) was once well-known among Malaysian and foreign tourists, dignitaries and royals. The traditional homes, including Rumah Seberang Baroh, Rumah Rhu Rendang, Rumah Kuala Ibai, and Rumah Atas Tol are aged about 100-200. "Tengku Ismail named them after the places they came or purchased from The interesting part is they were designed without nails, instead using wood joinery technique," said Md Fauzi Mustaffa, chairman of the Tanjung Sabtu Community Management Council (MPKK). The late Tengku Ismail, a member of the Terengganu royal family, was also instrumental in producing songs and made one of the houses into a workshop the putera songket (songket prince) pursued at home and abroad. Since September, with an enticing mystery tale, slow changes entered the royal residence [26].

For Pura Tanjung Sabtu, it has an exquisite Malay Architectural heritage but it will stand forlorn and forsaken if nobody looks after it. The restoration may cost a lot the local community believe if it is resurrected or turned into a heritage product such as into a museum or heritage village, it will generate good returns. It is such a loss if the palace is abandoned, even now due to its location which is near the river, anyone can enter via land or water to steal precious and ancient things like the pots and furniture. Some sets of steps are missing too. The local community claimed that they do not know who comes and goes and hopes someone, including the state government will consider taking over Pura Tanjung Sabtu to bring it back to its glory days.

As Terengganu is well-known for its tourism's spot, especially beaches and culture, this Pura Tanjung Sabtu can be one of the strategic spot for tourism sector because the setting is formed by economic, cultural and religious factors in this historical area apart from the identity space of local culture is strongly exists and the shift in the value of space, which has changed from the glory of the noble family to the common people. This two concepts are significantly potential for tourism. People living in the coastal zone were very open to foreigners and familiar with the trade activities which improved the economic situation [25]. This settlement is an important cultural heritage to be protected, as it incorporates local culture values. The setting system and the arrangement of space, time, context, communication, cultural land and physical elements are key factors for a tourist destination.

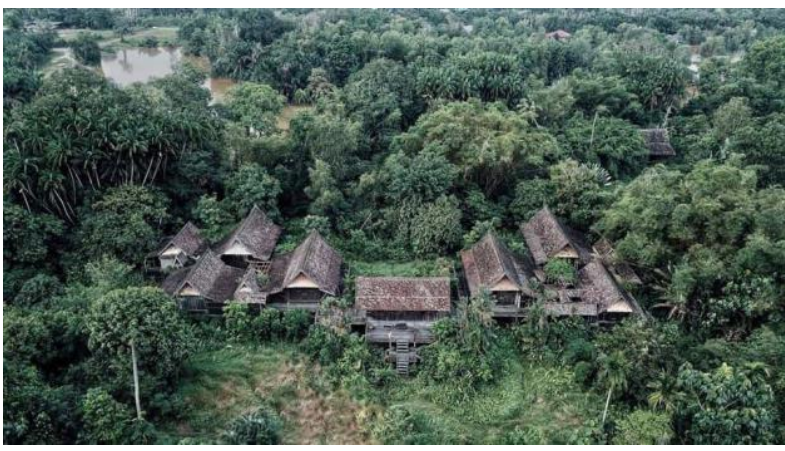

Figure 1 The Abandon Palace of Pura Tanjung Sabtu

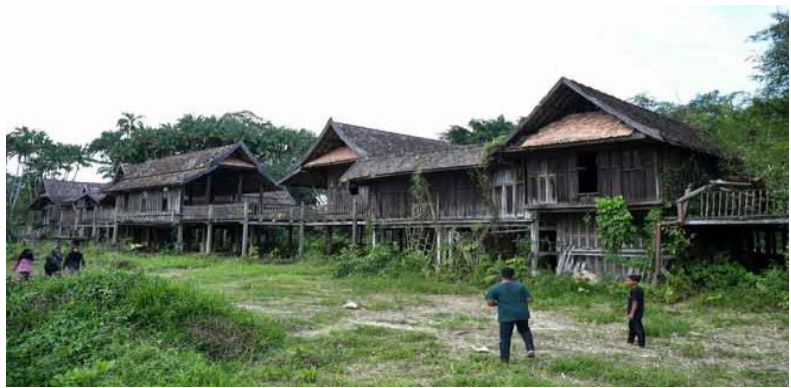

Figure 2 The close-up picture (Nowadays)

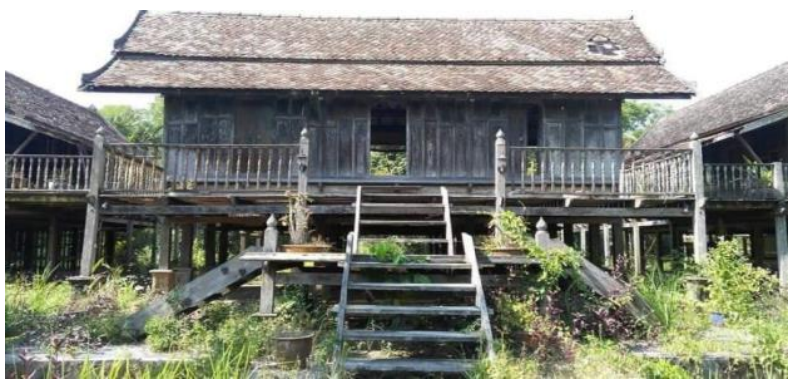

Figure 3 Pura Tanjung Sabtu (nowadays)

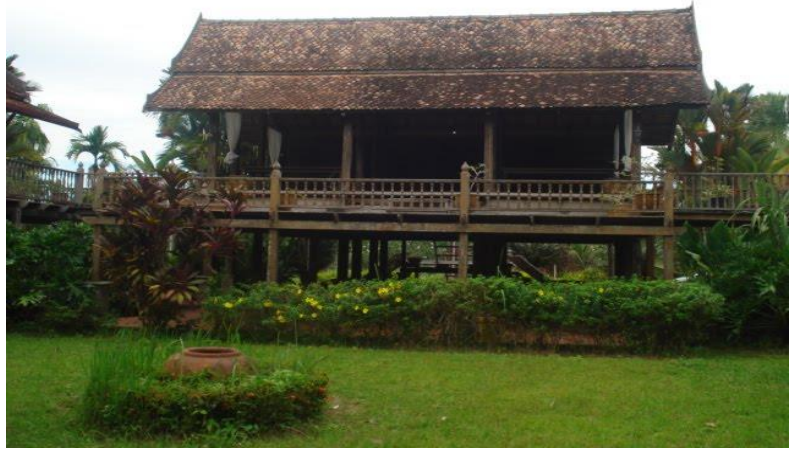

Figure 4 During its glory day (Before) 


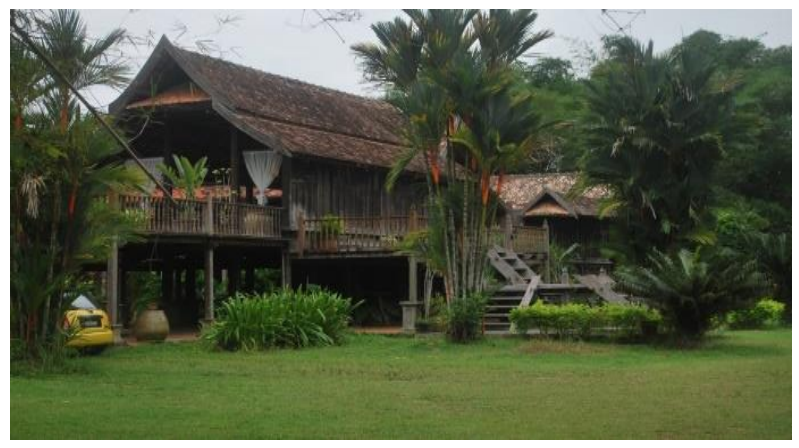

Figure 5 Pura Tanjung Sabtu during its glory day (Before)

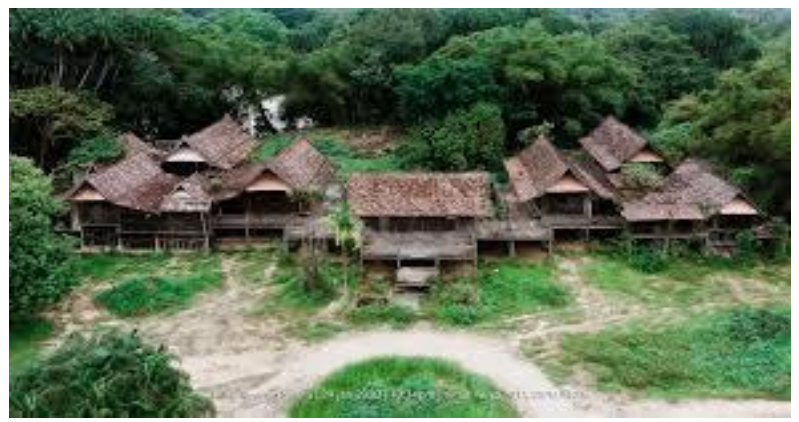

Figure 6 Pura Tanjung Sabtu (nowadays)

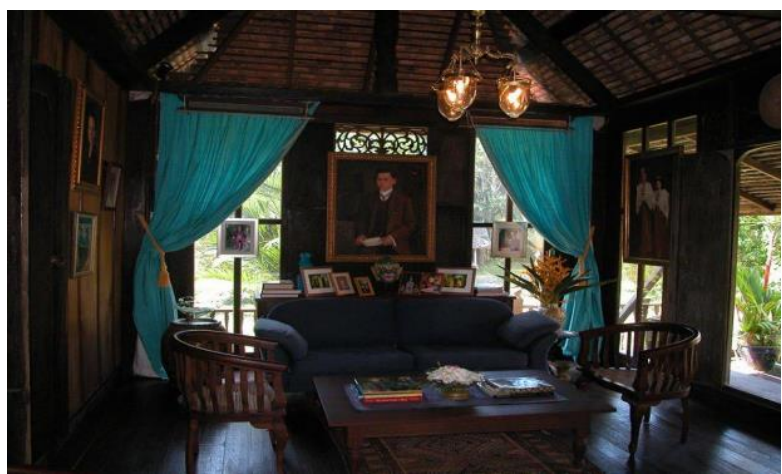

Figure 7 The internal belongings in Pura Tanjung Sabtu (some of the items were stolen, deteriorate) Sources: Internet sources

\section{METHODOLOGY}

This research employed a case-study design and a qualitative data was collected from April 2018 to July 2018 in Terengganu. In the case study of Pura Tanjung Sabtu, 20 members from the local community around the area were interviewed. The semi-structured interviews took around 20-30 minutes long. In order to make the participants more comfortable, some of the interviews were conducted in a group of two to 4 participants [27]. Overall, four one-to one interviews and 4 group interviews of four were formed. The participants included local people located around the heritage village which have different job background. Some of them are working as sales persons, private and government sector, and shop owners. The interview questions highlighted the role of $\mathrm{ICH}$ expressions in their daily routine, how they safeguarded their ICH and what are the possible efforts to be done in improving the current situation. Although the heritage village is the potential base for ICH's protection, most of the participants are unfamiliar with the term of ICH. Therefore, during the interview, the term of 'heritage traditions' was applied.

Additionally, to get a better explanation of how ICH is managed and to get an experts' perspective, the Director of Terengganu State Museum (1 interviewee) and the senior heritage officer at the National Department for Culture and Arts (3 interviewees) were interviewed on its management, policies and procedures for safeguarding $\mathrm{ICH}$, especially for heritage village. The semi-structured interviews were lasting between 40 and 60 min long.

Non-participant observation was also conducted in the heritage village. The researcher was led through the heritage village by a tour guide who also assisted in arranging the interviews. Even though this heritage village is not yet the 'national intangible heritage asset'

\section{RESEARCH SETTING}

Pura Tanjung Sabtu was once known for its exquisite and immaculate appearance of Malay Architechtural Heritage which stated at Manir, Terengganu. However, since its custodian, Tengku Ismail Tengku Su passed away in 2011, the palace which was established some 30 years ago, has failed to keep up its immaculate appearance, with mouldy floorboards in some parts and furniture no longer neatly positioned. Recently, the Terengganu government takes effort to recover Pura Tanjung Sabtu to ensure the building is restored and reawakened with full of treasures of Malay Tradition and has acknowledge the place to has potential as the cultural heritage tourism area. On another note, it could benefit the community as it helps the community in terms of economic wellbeing alongside sustaining their heritage values and tradition. Among the agenda was to introduce the Kampung Warisan (Heritage Village) concept although it requires many procedures to be refined and costly.

Pura Tanjung Sabtu is the existence of living heritage sites in Terengganu and it requires the participation and involvement of the specific group in the quest to preserve its cultural heritage and identity. The living heritage sites can generally be regarded as an attempt to represent or sustain the community's heritage and directly or indirectly help the said community and also its village to sustain. Hence, this research seeks to understand the stakeholders' perception and engagement on the re-development of Pura Tanjung Sabtu as the cultural heritage tourism area.

Tourism is one of Terengganu's main industry and it is a priority for all levels of government. The islands especially are included in the national plan for social and economic development and it is identified as one of the 
priority areas for tourism development (Shasila, 2016) [28]. Very recently, the eastern coast of Malaysia located at Kuala Terenganu, under East Coast Economic Region (ECER) together with Majlis Agama Islam and Adat Istiadat Melayu Terengganu have planted their interest in establishing Heritage Village and the proposed location is around the locus of Tanjung Sabtu. Tanjung Sabtu was known to have the exquisite architechture of Malay Heritage which believed to be the old palace, between 100 -200 years old. It got its name from a combination of the Sanskrit word Pura; meaning palace and Tanjung Sabtu; which is the name of the village where it was built. The Tanjung Pura Sabtu was built by the late YM Tengku Ismail YM Tengku Su in the early 90s. However, the buildings there are now obsolete and unmanageable after the owner passed away in 2011. Although the Terengganu government is currently examines the proposal for the conservation of Pura Tanjung Sabtu for the sake to ensure that the building is full of treasure of Malay Tradition and re-awakened, the state government had limited information about this building and further discussions with stakeholders is needed to manage the complex, especially the collaboration with the community of the area.

\section{FINDINGS AND DISCUSSION}

Interviews with the community members at Pura Tanjung Sabtu indicate that much of their cultural heritage traditions are no longer practiced in their daily routine because of other commitment such as working full-time or taking care of the family. However, they claimed that they are aware of the deterioration or slowly loss of the heritage and need to make a constant effort to safeguard them. Three categories of ICH were named that were attached to the interviewees. Firstly, was the heritage that still practiced by most members in the community, be it young and old. The tradition was the batik painting and songket weaving. It is the tradition from one generation to another and still be appreciated to the community. One interview stated that:

For me, the batik painting and songket weaving is our most crucial heritage. The skills of painting and crafting is handed down from our ancestors and the youngsters are still keen to learn these skills. That is why in this community, the batik and songket business is flourished because we have apprentices of this type of heritage.

Other traditions claimed by interviewees also included wedding rituals, oral tradition and songs.

Secondly, is the tradition that are still practiced, but gradually declining among younger group of people, especially among the more educated members of the community. For instance, the music of gamelan; one woman stated that many younger generations are not interested to involve in gamelan's music:

It is not that I want to forget completely my own heritage, especially in gamelan's music, although some of my family members belong to the gamelan's group in this community. I have my own focus and goals to achieve and I honestly think I am not attached with continuing this heritage

Thirdly, was the type of ICH expressions that are crucial for the interviewees, but are at stake of disappearing. These heritage still pretty much alive among the older people, men in their 70s, but are rarely excite the youth in the community, for example keris-making. The Keris is a traditional Malay dagger and a cultural emblem of the Malaysians. The Keris is meant not only to protect the wearer and owner physically, but also to carry mystical powers, which further protect their owner against further harm. The legend says the owner will know that the danger lurks if the Keris rattles in his sheath. The Keris form is very special and can't be found in any other knife or dagger in the world. It has curves or waves, which make the Keris special. The Keris is indeed an honourable item and part of the royal regalia. The elegance of Keris is complemented by the extensively carved wooden handle or hilt, often reflecting the form of a kingfisher or other natural artefacts.

While all of the interviewees aware of the importance of safeguarding the skills of keris-making, no one from the younger generation still possesses the skills although most of them had the experience of learning it when they were younger. Some of them are only able to craft very simple pattern.

Discussion about how to safeguard the ICH elements is also about the difficulties of learning and disseminating it in the current situation. Although the community felt that all of their cultural heritage were essential, many of the ICH elements are no longer part of the daily life and slowly forgotten. One of the interviewee claimed that:

'I understand why our tradition and heritage fades into obscurity although I personally think younger generation should immerse with their own tradition for example wedding ceremony or Wau (Kite) festivals. All traditional skills and knowledge are mainly practiced by older people. Learning heritage knowledge takes passion and patience, but not everybody will succeed, including myself'

Interviews also showed the perception on how ICH was safeguarded, where two interviewees had the perspectives that the safeguarding of ICH is slowly improving, but were uncertain if it was enough to protect heritage tradition in Malaysia. One interviewee mentioned that:

'I think heritage protection in Malaysia is gradually strengthened by the Government, including $\mathrm{ICH}$ elements. But to rely heavily on one side, will not enough. Community, local people and agencies should work together to find efficient solution for this matter'

Three interviewees mentioned their concern towards the ICH expression that might be permanently disappear. They stated:

'We are not sure if my future generation will have the chance to learn about our ICH. I think in 10 years time, the older people will die and it is quite possible that we will not have most of our heritage tradition anymore'. 
Most interviewees welcomed the proposal of developing the Pura Tanjung Sabtu to be a Heritage Village which they claimed it can be the crucial role in researching and documenting ICH, especially Terengganu's heritage. However, issues such as the local autonomy, the collaboration of local people and agencies must be clearly justified from both sides in order to avoid any further problems.

The interviewed expert justified that the role of Pura Tanjung Sabtu for the safeguarding of Terengganu's ICH as more critical. Although surrounds the area is the evidence of heritage's elements, he expressed: ' I think the potential of Pura Tanjung Sabtu as a Heritage Village would require more contemporary element. I don't see an inclusion of the changes that take place; the palace mainly focus on the original ancient or traditional ways of practicing the tradition'. Another expert claimed that the combination of tourism development and safeguarding ICH does not collaborate well in Pura Tanjung Sabtu

'Although tourism development is one way to protect $\mathrm{ICH}$, it is not really work here, it is hard to find the real Terengganu's culture and also the property of Pura Palace is a private property. The process of converting everything into a Heritage Village is far more complicated'

Those expert convinced that in order to safeguard the ICH in Terengganu, it has to be happened in situ, at the Tanjung Sabtu's village and get more involvement from the owner or close relatives belong to Pura Palace. The expert believed, a heritage village could hardly safeguard the diversity and complexity of ICH.

The local people had an overall good impression of Pura Tanjung Sabtu to be a Heritage Village and claimed that it might boost the local economy in the area. For them, the tradition or the culture exist around the community were less meaningful if no interference from the government to work hand in hand in assisting the community to participate in developing the cultural heritage tourism area. Furthermore, interview with the local people showed that since the government agencies slowly commercialize the culture in the area, its safeguarding efforts has improved significantly, which fits with the government's aim for the productive protection. The following statement articulated that:

'I believe that the government do help our cultural heritage to improve the economy. And since this proposal to develop a heritage village is a focus for potential stakeholders, it seems that the national government value the culture more. There has been more research'

When discussing the responses of the local community regarding the importance of heritage tradition to them, it becomes clearer that the idea to develop Pura Tanjung Sabtu to be a Heritage Village is welcomed, however, issues such as the local autonomy, the recognition, the incentives, and the knowledge transfer are the main concern for the local community. They need to be evidently informed and be involved in every processes of developing a Heritage Village in the area. Several respondents of the local people claimed:
'We are just local people who is trying to improve our living and by having this kind of development, it is something positive. However, we were also wanted to ensure this project will not be one-sided and the involvement of local community should be the priority for the relevant authority such as the benefits or the knowledge gained for the local community when engaging with other stakeholders'

'I do hope this Pura Tanjung Sabtu will somehow contribute to the protection of our cultural heritage and boost Terengganu's tourism sector, but in the same time, I was worried if the involvement of local community and the benefits for the people is shunned away or denied'

It is interesting to note of the different perceptions on the efficiency of safeguarding ICH which can be resulted from the various understandings of what makes the effectiveness of ICH-protection work. From the local people's point of view, the protection of cultural heritage is consist mainly for inventorying and documenting, while from the expert's view, it consists of many layers of process and procedures with SOPs that to be adhered.

The real issue for Pura Tanjung Sabtu is the ownership and the land area of the building. Due to private property and yet no action or decision made by the close relatives or acquaintance in regards of the heritage building, there is not much can be done by other potential stakeholders. According to one of the heritage officer, he stated;

'The Terengganu's authority aware of the heritage property at Tanjung Sabtu and was planning to develop something beneficial for the local community, and it is of course to increase the niche area for Terengganu State, which is tourism. However, we received less information in regards of the ownership, documentation, authorization of the property. Without having a solid proof of everything needed to start a project, we could not do much and definitely will incur bigger issues in the future if we proceed on the intention to develop a heritage village at Tanjung Sabtu'

Nevertheless, a major issue remain. The ownership of the heritage property. It seems to be a prolific spot for tourism development, but if there is none official clarification made, therefore it will be out of context, thus representing its major challenge in safeguarding ICH at Terengganu.

\section{CONCLUSION}

The results of this paper show that Pura Tanjung Sabtu offers numerous opportunities and challenges for ICH security. It primarily supports the safeguarding of ICH customs and inventories through funding research at present. The future heritage village has enhanced the pride of the local community and inspired others to learn about ICH from Terengganu. However little effort has been made to convey the culture of $\mathrm{ICH}$ to the young generation and to invest in education. The main obstacle for the Heritage Village, as well as for most heritage conservation projects in Malaysia, is that the 
government's political agenda and tourism growth influence decision making on ICH security. Overall, it can be concluded that while $\mathrm{ICH}$, profoundly rooted in its environments, in a cultural heritage approach is difficult to safeguard, it can make a substantial contribution to the conservation of $\mathrm{ICH}$. While the notion of productive security is problematic and encourages a heavy emphasis on handicraft, it can also be of benefit. A heritage village has a lot of financial capital, if successful. Local community members who work in the heritage village have the ability to present and connect with visitors in their own version of their cultural heritage practises. The key requirements to contribute to the security of the $\mathrm{ICH}$ are that the local people should be involved in the safeguard process by, for example taking on management roles and concentrating more on education and transmission.

\section{REFERENCES}

[1] Yang, L., and G. Wall. 2008. "Ethnic Tourism and Entrepreneurship: Xishuangbanna, Yunnan, China." Tourism Geographies 10 (4): 522-544

[2] Oakes, T. 1998. Tourism and Modernity in China. London: Routledge.

[3] Z. Hongxia and Z. Changzhi, A Library's Efforts en route to Salvaging a Vanishing Culture. In World Library and Information Congress: 73rd Annual International Federation of Library Associations (IFLA) General Conference and Council, Durban, South Africa. (2007) 19-23.

[4] I. Johnson, In China,'Once the Villages Are Gone, the Culture Is Gone'.". New York Times, 2, 2014.(2014). https://

www.nytimes.com/2014/02/02/world/asia/once-thevillages-are-gone-the-culture-is-gone.html.

[5] K. Howard, East Asian Music as Intangible Cultural Heritage. (2012).

[6] W. S. Logan, Closing Pandora's box: human rights conundrums in cultural heritage protection. In Cultural heritage and human rights. Springer, New York, NY.(2007) 33-52.

[7] UNESCO. 2003. Convention for the Safeguarding of the Intangible Heritage. www.unesdoc.unesco.org. images/0013/001325/132540e.pdf

[8] Pan, S. 2008. "Museums and the Protection of Cultural Intangible Heritage." Museum International 60 (1-2): 12-19

[9] De Cesari, C. 2012. "Thinking Through Heritage Regimes." In Heritage Regimes and the State, edited by
R. F. Bendix, A. Eggert and A. Peselmann, 399-413. Göttingen: Universitätsverlag Göttingen

[10] K. E. Kuah and Z. Liu, From "folk culture" to "great cultural heritage of China": the aporia of the quest for the essence of Chinese culture JUNG-A CHANG. In Intangible Cultural Heritage in Contemporary China (2016) 124-148. Routledge

[11] Lixinski, L. 2013. Intangible Cultural Heritage in International Law. Oxford: Oxford University Press

[12] A. Laishun and J. A. Gjestrum, The ecomuseum in theory and practice. The first Chinese ecomuseum established. Nordisk Museologi, (2) (1999) 65-65.

[13] Su Che Park, 2011. Ecomuseums: A Sense of Place. 2nd ed. London: Continuum.

[14] Amerta MacCannell, 1992. Empty Meeting Grounds: The Tourist Papers. London: Routledge

[15] Dewi, C. (2017). Rethinking architectural heritage conservation in post-disaster context. International Journal of Heritage Studies, 587-600.

[16] Syafi'i, M., et al. (2015). Tourism village planning concept ap-proach community based tourism [Case Study: Bedono Vil-lage, Sayung, Demak]. Ruang, 1(2), 51-60

[17] Santoso, 2013. "Authenticating Ethnic Tourism: Li Dancers' Perspectives." Asia Pacific Journal of Tourism Research 10 (1): 1-21

[18] Zahnd, 2005, Authenticating Ethnic Tourism: Li Dancers' Perspectives." Asia Pacific Journal of Tourism Research 10 (1): 1-21

[19] Ishomuddin, S. A. (2005). Sosiologi Perspektif Islam [Islamic Per-pective Sociology]. Malang: Universitas Muhamadiyah

[20] Habraken, N. J., et al. (1976). Variations, the systematic design of supports. Cambridge: MIT Press.

[21] Rapoport, A. (2000). Theory, culture, and housing. Housing, Theory and Society, 17(4), 145165.

[22] Rossi, A., \& Eisenman, P. (1982). The architecture of the city. The MIT Press.

[23] Higgins, P. (2014). Quality of life and spatial inequality in Lon-don. European Urban and Regional Studies, 21(1), 42-59 
[24] Marlina, A. (2017). Residential space transformation as the le-gitimacy space a case study: Magersari Ndalem Sasanamulya Baluwarti Sunanate Palace Of Surakarta. IOP Conference Se-ries: Earth and Environmental Sciences, 213 (2018),

[25] A. Suprapti, A. B. Sardjono, I. Indriastjario and E. E. Pandelaki, The spatial concepts of cultural heritage village toward a tourism development; A case study of Kadilangu Demak Indonesia. Journal of Architecture and Urbanism, 43(1) (2019) 36-46. https://doi.org/10.3846/jau.2019.6057

[26]https://www.thestar.com.my/news/nation/2020/01/1 6/palace-abandoned-and-left-to-rot

[27] A. Bryman, Social research methods. Oxford university press. (2016).

[28] Shasila Ramly. 2016. The implication of heritage village in tourism sector. International Journal of Tourism: 30 (2) 77-83 